\title{
Effect of pigmenting agents on tooth enamel staining during immediate tooth whitening: an in vitro study
}

\author{
Efeito de agentes pigmentantes no manchamento do esmalte dental durante \\ o clareamento dentário imediato: estudo in vitro
}

\author{
Daniela Luzimar CLAUDINOa (iD, João Victor Frazão CÂMARA ${ }^{\text {b* }}$ (D), Osmar de AGOSTINHO NETOc (D), \\ Ericles Otávio SANTOS ${ }^{d}\left(\mathbb{D}\right.$, Gisele Damiana da Silveira PEREIRA ${ }^{a}$ (D), Isabel Ferreira BARBOSA ${ }^{e}$ (D) \\ aUFRJ - Universidade Federal do Rio de Janeiro, Faculdade de Odontologia, Departamento de Clínica Odontológica, Rio \\ de Janeiro, RJ, Brasil \\ bUSP - Universidade de São Paulo, Faculdade de Odontologia de Bauru, Departamento de Ciências Biológicas, Bauru, \\ $\mathrm{SP}$, Brasil \\ 'UFRJ - Universidade Federal do Rio de Janeiro, Faculdade de Odontologia, Departamento de Prótese e Materiais \\ Dentários, Rio de Janeiro, RJ, Brasil \\ dUFRJ - Universidade Federal do Rio de Janeiro, Faculdade de Odontologia, Departamento de Odontopediatria e \\ Ortodontia, Rio de Janeiro, RJ, Brasil \\ eUNICAMP - Universidade Estadual de Campinas, Faculdade de Odontologia de Piracicaba, Departamento de \\ Dentística Restauradora, Campinas, SP, Brasil
}

\begin{abstract}
How to cite: Claudino DL, Câmara JVF, Agostinho Neto O, Santos EO, Pereira GDS, Barbosa IF. Effect of pigmenting agents on tooth enamel staining during immediate tooth whitening: an in vitro study. Rev Odontol UNESP. 2020;49:e20200045. https://doi.org/10.1590/1807-2577.04520
\end{abstract}

\begin{abstract}
Resumo
Introdução: Com o aumento da procura por procedimentos estéticos, dúvidas surgem quanto à manutenção e regressão de cor, especialmente, no que tange a necessidade de restrição quanto à alimentos escuros durante o procedimento clareador ou a sua influência quanto à estabilidade e eficácia do tratamento. Objetivo: Avaliar a influência de agentes pigmentantes sobre o esmalte dental durante o tratamento clareador imediato com peróxido de hidrogênio a 35\%. Material e método: 60 dentes bovinos foram divididos em 6 grupos (G) (n=10): G1: água destilada (controle), G2: café, G3: refrigerante à base de cola, G4: vinho, G5: chá-mate, e G6: açaí industrializado. As amostras foram submetidas ao clareamento imediato utilizando peróxido de hidrogênio a 35\% durante 21 dias (3 aplicações de 15 minutos por sessão a cada 7 dias) e submetidas à imersão dos pigmentos entre cada sessão durante 15 minutos. A avaliação da cor foi realizada antes do inicio do clareamento e após 21 dias, mediante o uso do espectrofotômetro. Os dados obtidos foram submetidos ao ANOVA one-way e análise de heterocedasticidade pelos testes de Welch e Brown-Forsythe. 0 teste de Tamhane foi utilizado para a comparação entre os grupos. Resultado: Houve alteração de cor visível ao olho nu, uma vez que a média de $\Delta \mathrm{E}$ em todos os grupos testados foi maior que 3,7. Contudo, não houve diferença estatística entre o grupo controle em relação aos grupos avaliados. Conclusão: 0 contato de agentes pigmentantes no esmalte dental bovino não influenciou o resultado final do clareamento dental imediato.
\end{abstract}

Descritores: Clareamento dental; peróxido de hidrogênio; corantes; pigmentação.

\begin{abstract}
Introduction: Considering the increased search for esthetic procedures, questions emerge about the maintenance and regression of color, especially regarding the need to restrict dark foods during bleaching procedures or their influence on the stability and effectiveness of the treatment. Objective: To assess the influence of staining agents on tooth enamel during immediate bleaching treatment with 35\% hydrogen peroxide. Material and method: Sixty bovine teeth were divided into six groups (G) (n=10): G1: distilled water (control); G2: coffee; G3: cola soft drink; G4: wine; G5: mate tea; and G6: industrialized açaí. The samples were subjected to immediate bleaching using 35\% hydrogen peroxide for 21 days (three applications of 15 minutes per session, every seven days) and pigment immersion between each session for 15 minutes. The color was assessed before starting bleaching and after 21 days, using a spectrophotometer.
\end{abstract}


The data obtained were subjected to one-way ANOVA and heteroscedasticity analysis by the Welch and Brown-Forsythe tests. The Tamhane test was used for group comparison. Result: The color change was visible to the naked eye, considering the mean $\Delta \mathrm{E}$ in all groups tested was higher than 3.7. However, there was no statistical difference between the control group and the groups assessed. Conclusion: The contact of staining agents on bovine tooth enamel did not affect the final result of the immediate tooth bleaching.

Descriptors: Tooth bleaching; hydrogen peroxide; dyes; staining.

\section{INTRODUCTION}

Smile harmony has a great influence on the life of patients, especially in the social aspect. The esthetic appearance of teeth is extremely important because white teeth are associated with both beauty and health ${ }^{1}$. Considering the increased search for cosmetic procedures, questions emerge about the maintenance and regression of color, especially regarding tooth bleaching2,3.

The difference between the types of staining is well established in the literature and divided into two main groups: intrinsic and extrinsic ${ }^{4,5}$; The first has pigments integrated to the enamel and/or dentin structure and it is harder to remove, while the latter occurs due to diet habits, with the deposition of chromogenic substances, and it is easier to treat ${ }^{6,7}$. The treatment for both is also extensively established in the literature and divided into three techniques: mediate, immediate, and combined $8-10$. Its action mechanism has not been fully described but the more accepted theories are that bleaching agents, through oxidation, cleave the extensive conjugated chains that form the pigments, thus reducing the number of staining molecules ${ }^{11}$.

Dentists also often recommend that patients control the ingestion of darker-colored products such as coffee, teas, and wine during bleaching procedures, thus performing a white diet. This mostly appears in the written instructions of the leaflets of products in this field or it is recommended because of the lack of information from previous generations that believed in internal staining caused by external agents. Considering that several authors have reported tooth discoloration and staining by agents such as wine and coffee ${ }^{12-14}$, the need to restrict dark foods during the bleaching procedure has not been confirmed, as well as their influence on the stability and effectiveness of the treatment ${ }^{15}$.

Decalcification, porosities, and topographic changes in tooth enamel are promoted ${ }^{16,17}$, favoring discoloration and pigment build-up in teeth. However, the mineral loss is compensated by the remineralization properties of saliva ${ }^{18}$, which contains calcium and phosphate ions. Moreover, the carbamide peroxide, when dissociating into ammonia and carbon dioxide, increases the $\mathrm{pH}$ of the bleaching agent for 15 minutes and makes the oral cavity environment more basic, decreasing this demineralization even more ${ }^{19,20 .}$

In this sense, as an impact on the questions that emerge for the type of diet after tooth bleaching, especially regarding industrialized beverages, this study aimed to assess in vitro the influence of different staining agents on tooth enamel during the immediate bleaching treatment with 35\% hydrogen peroxide. The null hypothesis is that staining agents do not affect the result during tooth bleaching performed with 35\% hydrogen peroxide when applied to bovine tooth enamel.

\section{MATERIAL AND METHOD}

\section{Obtaining, Cleaning, and Storing the Teeth}

Sixty healthy bovine teeth were used in this study (Frigorífico Mondelli Indústria de Alimentos S/A, Bauru, SP, Brazil). The teeth were stored for one month in an $8 \%$ thymol solution after their extractions. For specimen preparation, the enamel surfaces were polished with \#600 silicon 
carbide sandpapers (Carborundum Abrasivos, São Paulo, SP, Brazil) in a polisher (Instituto Alberto Luiz Coimbra de Pós-Graduação e Pesquisa em Engenharia, COPPE, Cidade Universitária, UFRJ, Rio de Janeiro, Brazil) for a standardized time of 30 seconds. For the first part of the study, a condensation silicone mold (heavy base) was produced in the buccal aspect of one single specimen to standardize the positioning during the spectrophotometer reading.

\section{Experimental Groups}

Sixty bovine teeth were used, distributed into six experimental groups $(\mathrm{n}=10)$ :

Group 01 - Immediate bleaching with 35\% hydrogen peroxide, once a week, three applications of 15 minutes, according to the manufacturer's instructions, resulting in 45 minutes per session. After each weekly session, the bovine teeth were stored in artificial saliva for 24 hours and then immersed in distilled water for 15 minutes daily. Next, the bovine teeth were again stored in artificial saliva for the remaining time (positive control group).

Group 02 - Immediate bleaching with 35\% hydrogen peroxide, once a week, three applications of 15 minutes, according to the manufacturer's instructions, resulting in 45 minutes per session. After each weekly session, the bovine teeth were stored in artificial saliva for 24 hours and then immersed in coffee for 15 minutes daily. Next, the bovine teeth were again stored in artificial saliva for the remaining time.

Group 03 - Immediate bleaching with 35\% hydrogen peroxide, once a week, three applications of 15 minutes, according to the manufacturer's instructions, resulting in 45 minutes per session. After each weekly session, the bovine teeth were stored in artificial saliva for 24 hours and then immersed in a cola soft drink for 15 minutes daily. Next, the bovine teeth were again stored in artificial saliva for the remaining time.

Group 04 - Immediate bleaching with 35\% hydrogen peroxide, once a week, three applications of 15 minutes, according to the manufacturer's instructions, resulting in 45 minutes per session. After each weekly session, the bovine teeth were stored in artificial saliva for 24 hours and then immersed in red wine for 15 minutes daily. Next, the bovine teeth were again stored in artificial saliva for the remaining time.

Group 05 - Immediate bleaching with 35\% hydrogen peroxide, once a week, three applications of 15 minutes, according to the manufacturer's instructions, resulting in 45 minutes per session. After each weekly session, the bovine teeth were stored in artificial saliva for 24 hours and then immersed in mate tea for 15 minutes daily. Next, the bovine teeth were again stored in artificial saliva for the remaining time.

Group 06 - Immediate bleaching with 35\% hydrogen peroxide, once a week, three applications of 15 minutes, according to the manufacturer's instructions, resulting in 45 minutes per session. After each weekly session, the bovine teeth were stored in artificial saliva for 24 hours and then immersed in industrialized açaí for 15 minutes daily. Next, the bovine teeth were again stored in artificial saliva for the remaining time.

\section{Tooth Bleaching}

For the immediate bleaching of bovine teeth, the Whiteness HP 35\% hydrogen peroxide bleaching gel was used. The hydrogen peroxide gel was handled according to the manufacturer's recommendations, which consists of mixing three drops of 35\% hydrogen peroxide to one drop of thickener. The gel was applied directly on the buccal surfaces in the enamel of bovine teeth, which were partially immersed in artificial saliva, leaving the buccal surfaces exposed, and the Whiteness HP bleaching gel filled the entire bleaching area. Bleaching was performed in vitro and, according to the manufacturer's instruction, the gel remained in contact with the enamel for 
45 minutes in three applications of 15 minutes, resulting in three treatment sessions with a 7-day interval between each session. During the sessions, the specimens remained exposed to room temperature. The gel was removed with flexible plastic rods with cotton on the ends (Cotonetes - Johnson \& Johnson, Brazil) and then washed abundantly in running water. Later, the bovine teeth were again stored in artificial saliva at room temperature, with the crown completely immersed. The artificial saliva was replaced once a week after each bleaching session to maintain its properties.

\section{Staining Protocol}

The samples from group 02 were stained with coffee (Nescafé Tradição, Nestlé ${ }^{\mathrm{m}}$, Switzerland) containing $5 \mathrm{~g}$ of sugar (União Cristalçúcar) mixed with a teaspoon equivalent to $3 \mathrm{~g}$, which was obtained with a digital scale. Then, the portion was dissolved in $50 \mathrm{ml}$ of boiling water, as suggested by the manufacturer, and agitated for about three minutes. Staining was performed by immersing the specimens in coffee for 15 minutes, considering this time was determined by the manufacturers who established it as the average time to drink a cup of coffee, and among coffee drinkers, to whom the average intake is 3.2 cups a day ${ }^{21}$.

The samples from the other groups (03 - cola soft drink; 04 - red wine; 05 - mate tea; and 06 açaí) were stained by immersing the specimens in their respective staining agents without changes in preparation for the standardized time of 15 minutes daily, once a day. Next, the samples were washed in running water and returned to storage in artificial saliva until the next staining session.

\section{Color Analysis}

The color was analyzed on enamel at two different moments. The initial moment occurred before starting bleaching ( $\mathrm{t} 0$ ) with the bovine teeth having been stored for 24 hours in artificial saliva. The second moment occurred after three weeks, at the end of bleaching/staining (tf). For the color readings, the bovine teeth were placed in the condensation silicone mold (heavy base) for standardization. A Vita Easyshade ${ }^{\mathrm{TM}}$ Advance 4.0 spectrophotometer (VITA Zahnfabrik H. RauterGmbH \& Co, BadSäckingen, Germany) was used, previously calibrated according to the manufacturer's recommendations. The color was determined using the parameters quantified in the CIE Lab system with three coordinates: $\mathrm{L}^{*}\left(\mathrm{a}^{*}\right)$ and $\left(\mathrm{b}^{*}\right)$, where $\mathrm{L}^{*}$ represents the tooth value in a scale from 0 (black) to 100 (white) and $a^{*}$ and $b^{*}$ represent the shadow, where ( $a^{*}$ ) is the measure along the red axis (positive $\mathrm{a}^{*}$ ) - green axis (negative $\mathrm{a}^{*}$ ) and $\left(\mathrm{b}^{*}\right)$ is the measure along the yellow axis (positive $b^{*}$ ) - blue axis (negative $b^{*}$ ). The color comparison before and after bleaching will be determined by the difference between both colors $(\Delta \mathrm{E})$, which will be calculated with the formula: $\Delta \mathrm{E}=[(\Delta \mathrm{L}) 2+(\Delta \mathrm{a}) 2+(\Delta \mathrm{b}) 2] 1 / 2$. When $\Delta \mathrm{E}$ is higher than 3.7 , an easily visible difference is considered; when it is between 3.7 and 1 , a clinically acceptable difference is considered; and when $\Delta \mathrm{E}$ is lower than 1 , a clinically non-perceptible difference is considered ${ }^{22}$.

\section{Statistical Analysis}

The data obtained were analyzed with the SPSS software, version 13.0. All the data obtained were subjected to one-way analysis of variance (one-way ANOVA) and, due to heteroscedasticity conditions, to the Welch and Brown-Forsythe tests. The Tamhane test was used for group comparison ( $5 \%$ significance level). 


\section{RESULT}

Table 1 presents the $\Delta \mathrm{E}$, mean, and standard deviation values obtained in the experimental conditions established.

The result shows a significant difference between the mean values obtained for $\Delta \mathrm{E}(\mathrm{p}<0.05 \%$; one-way ANOVA) (Table 2). The graphic analysis of the groups clearly shows the irregular behavior of the treatment given to group 04 (higher variability). Group 03 had more homogeneous behavior in the set of samples (Figure 1).

Thus, considering heteroscedasticity conditions, the Welch and Brown-Forsythe tests were applied, again showing a significant difference between the means of the groups $(\mathrm{p}<0.05 \%)$.

Lastly, the intergroup comparative analysis showed a significant difference only between groups 02 and $03(\mathrm{p}=0.01 \%$, Tamhane test), while the comparisons between the other groups had no significant differences ( $p>0.05 \%$, Tamhane test) (Table 2).

Table 1. Color change values $(\Delta \mathrm{E})$ of the six experimental conditions in the analysis of tooth enamel staining by consuming staining agents during the immediate bleaching treatment with $35 \%$ hydrogen peroxide

\begin{tabular}{|c|c|c|c|c|c|c|}
\hline Group & 1 & 2 & 3 & 4 & 5 & 6 \\
\hline \multicolumn{7}{|l|}{ Sample } \\
\hline 1 & 10.82 & 13.16 & 2.25 & 16.4 & 5.58 & 6.06 \\
\hline 2 & 0.99 & 16.66 & 4.92 & 5.84 & 7.49 & 2.72 \\
\hline 3 & 3.04 & 12.43 & 4.74 & 8.26 & 3.37 & 5.46 \\
\hline 4 & 8.01 & 2.47 & 2.87 & 15.03 & 3.89 & 2.06 \\
\hline 5 & 4.28 & 5.98 & 4.77 & 3.51 & 4.65 & 3.48 \\
\hline 6 & 2.32 & 14.02 & 1.9 & 10.08 & 16.56 & 7.48 \\
\hline 7 & 7 & 9.13 & 3.93 & 6.33 & 11.26 & 4.59 \\
\hline 8 & 4.7 & 10.15 & 5.2 & 28.08 & 12.48 & 8.85 \\
\hline 9 & 4.79 & 10.39 & 2.65 & 12.53 & 4.2 & 4.07 \\
\hline 10 & 1.52 & 7.5 & 3.75 & 8.23 & 2.92 & 5.34 \\
\hline Mean & 4.75 & 10.19 & 3.70 & 11.43 & 7.24 & 5.01 \\
\hline Maximum & 10.82 & 16.66 & 5.20 & 28.08 & 16.56 & 8.85 \\
\hline Minimum & 0.99 & 2.47 & 1.90 & 3.51 & 2.92 & 2.06 \\
\hline Standard deviation & 3.09 & 4.16 & 1.21 & 7.14 & 4.64 & 2.10 \\
\hline
\end{tabular}

Table 2. One-way ANOVA ( $p<0.05 \%$ ). Different lower-case letters horizontally represent significant differences between the groups assessed. (Tamhane test, 95\% confidence interval)

\begin{tabular}{ccccccc}
\hline Groups & $\mathbf{1}$ & $\mathbf{2}$ & $\mathbf{3}$ & $\mathbf{4}$ & $\mathbf{5}$ & $\mathbf{6}$ \\
\hline $\mathbf{\Delta E}$ & $4.75( \pm 3.09) \mathrm{ab}$ & $10.14( \pm 4.16) \mathrm{a}$ & $3.70( \pm 1.21) \mathrm{b}$ & $11.43( \pm 7.14) \mathrm{ab}$ & $7.24( \pm 4.64) \mathrm{ab}$ & $5.01( \pm 2.10) \mathrm{ab}$ \\
\hline
\end{tabular}

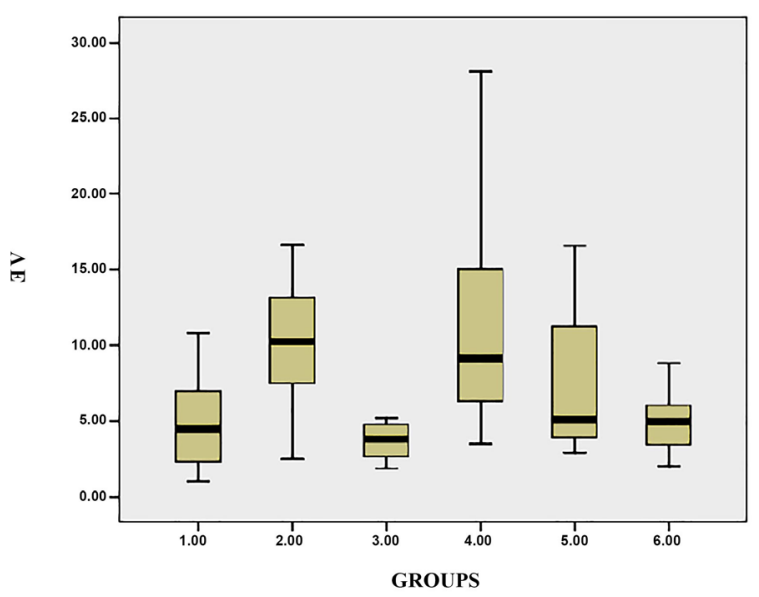

Figure 1. Graphic representation of the mean $\Delta \mathrm{E}$ of the samples in the groups assessed. 


\section{DISCUSSION}

The study assessed the influence of different staining agents on the color change of tooth enamel, which may occur during the immediate bleaching treatment. Bovine teeth were used because of the morphological and histological similarity to human teeth ${ }^{23}$, the uniform composition, and the ease of obtaining and standardizing them ${ }^{24}$. The color was analyzed with an objective method that promotes more reliable and accurate results, named spectrophotometry 22 , when compared to the results obtained with the visual method, thus preventing the interference of personal factors. Moreover, the bovine teeth used in the study were stored in artificial saliva, simulating the remineralization in the oral cavity ${ }^{15,21}$, which may reverse the erosion process and porosities caused by bleaching agents with low $\mathrm{pH}$ and oxidative ability.

The results in this study showed a color change visible to the naked eye, considering the mean $\Delta \mathrm{E}$ in all the groups tested was higher than 3.7 (Table 1). As shown by De Geus et al. ${ }^{22}$, a $\Delta \mathrm{E}$ mean higher than 3.7 is considered a clinically acceptable difference in comparison with measures lower than 3.7, and it is clinically visible.

Moreover, the result of the present study did not show a significant difference between the control group and the other groups assessed (Table 2). Thus, the null hypothesis was accepted. A study by Côrtes et al.10, 2013 showed that during tooth bleaching, the staining agents cannot change treatment effectiveness but using the same pigments caused losses of the results obtained in the post-treatment phase, specifically during the ingestion of wine and coffee. It also reported that even if the enamel is susceptible to extrinsic staining when immersed in different fluids, the susceptibility of additional staining does not increase.

Another study by Matis et al.15, 2015 showed that individuals that consumed red wine or dark fruits did not present changes in enamel color when compared with individuals who did not consume such staining agents, which concludes that adhering to a white diet during the tooth bleaching process did not improve the esthetic result of tooth bleaching.

However, the study by Berger et al. ${ }^{4}, 2008$ indicates that beverages containing dyes with an acidic $\mathrm{pH}$ may affect negatively the effectiveness of tooth bleaching, changing the topography of enamel and allowing staining after consuming staining agents. Nonetheless, the authors tested the staining immediately after bleaching and for a long exposure time ( 1 hour and 48 hours), which may show results that do not reflect the clinical reality of patients.

It is believed that the extrinsic staining of teeth by dying agents such as tea, red wine, cocoa, coffee, grape, pear, apple, passion fruit, pomegranate, açaí, nuts, almond, clove, cinnamon, red beans, among others results from the deposition of tannins on the tooth surface. The connection of tannins or other polyphenols to the hydroxyapatite component of the enamel may be exacerbated by salivary proteins. The enamel permeability, which allows ion exchanges between tooth and saliva ${ }^{6}$ facilitates the entry of ions and substances with a low molecular weight in the dental structure, such as bleaching agents and staining substances. These pigments in the oral cavity may penetrate the enamel and reach the dentin, causing dental staining, which cannot be removed with prophylaxis.

Another important aspect to highlight is that these substances consist of macromolecular chains and, therefore, are hardly able to permeate through human enamel, which allows only the passage of molecules with low molecular weight. Tooth enamel works as a semipermeable membrane that allows the passage of ions and small molecules, therefore, the bleaching process does not occur in the structure of the mineralized enamel but possibly as a result of the oxidation of organic tissues in the human dentin.

Previous studies showed that bleaching may increase enamel roughness ${ }^{10,17}$. However, the present study corroborates recent ones that do not show changes in topography or staining after the bleaching process, which is likely explained by the differences in the methodologies used. Moreover, the addition of calcium and fluoride to the bleaching gel and the presence of artificial 
saliva decreased the loss in microhardness and increased enamel surface smoothness in the bleaching process, making the teeth less susceptible to staining. The in vitro trial is not a full representation of the clinical response but it takes on importance in the control and development of a base for the next research stage. Bovine teeth are often used due to their availability and surface size and for presenting morphological characteristics and physical properties similar to human teeth ${ }^{25}$, however, further studies are required to investigate the relationship between diet and tooth bleaching, advancing to in situ and in vivo models.

\section{CONCLUSION}

Based on the experimental conditions of this study and within the limitations of an in vitro research, it may be concluded that:

- Bleaching occurred with color changes visible to the naked eye because the mean $\Delta \mathrm{E}$ in all the groups tested was higher than 3.7;

- The contact of staining agents on bovine tooth enamel did not affect the final result of immediate tooth bleaching with $35 \%$ hydrogen peroxide.

\section{REFERENCES}

1. Barghi N. Making a clinical decision for vital tooth bleaching: at-home or in-office? Compend Contin Educ Dent. 1998 Aug;19(8):831-8, quiz 840. PMid:9918107.

2. Samorodnitzky-Naveh GR, Geiger SB, Levin L. Patients' satisfaction with dental esthetics. J Am Dent Assoc. 2007 Jun;138(6):805-8. http://dx.doi.org/10.14219/jada.archive.2007.0269. PMid:17545270.

3. Attia ML, Aguiar FHB, Mathias P, Ambrosano GMB, Fontes CM, Liporoni PCS. The effect of coffee solution on tooth color during home bleaching applications. Am J Dent. 2009 Jun;22(3):175-9. PMid:19650600.

4. Berger SB, Coelho AS, Oliveira VAP, Cavalli V, Giannini M. Enamel susceptibility to red wine staining after 35\% hydrogen peroxide bleaching. J Appl Oral Sci. 2008 Jun;16(3):201-4. http://dx.doi.org/10.1590/S1678-77572008000300007. PMid:19089218.

5. Goldberg M, Grootveld M, Lynch E. Undesirable and adverse effects of tooth-whitening products: a review. Clin Oral Investig. 2010 Feb;14(1):1-10. http://dx.doi.org/10.1007/s00784-009-0302-4. PMid:19543926.

6. Reis A, Dalanhol AP, Cunha TS, Kossatz S, Loguercio AD. Assessment of tooth sensitivity using a desensitizer before light-activated bleaching. Oper Dent. 2011 Jan-Feb;36(1):12-7. http://dx.doi.org/10.2341/10-148-CR. PMid:21488723.

7. Lima DANL, Aguiar FHB, Liporoni PCS, Munin E, Ambrosano GMB, Lovadino JR. In vitro evaluation of the effectiveness of bleaching agents activated by different light sources. J Prosthodont. 2009 Apr;18(3):249-54. http://dx.doi.org/10.1111/j.1532-849X.2008.00420.x. PMid:19210610.

8. Josey AL, Meyers IA, Romaniuk K, Symons AL. The effect of a vital bleaching technique on enamel surface morphology and the bonding of composite resin to enamel. J Oral Rehabil. 1996 Apr;23(4):244-50. http://dx.doi.org/10.1111/j.1365-2842.1996.tb00848.x. PMid:8730271.

9. McEvoy SA. Chemical agents for removing intrinsic stains from vital teeth. II. Current techniques and their clinical application. Quintessence Int. 1989 Jun;20(6):379-84. PMid:2756093.

10. Côrtes G, Pini NP, Lima DANL, Liporoni PCS, Munin E, Ambrosano GMB, et al. Influence of coffee and red wine on tooth color during and after bleaching. Acta Odontol Scand. 2013 Nov;71(6):1475-80. http://dx.doi.org/10.3109/00016357.2013.771404. PMid:23421870. 
11. Cavalli V, Arrais CAG, Giannini M, Ambrosano GMB. High concentrated carbamide peroxide bleaching agents effects on enamel surface. J Oral Rehabil. 2004 Feb;31(2):155-9. http://dx.doi.org/10.1111/j.1365-2842.2004.01138.x. PMid:15009600.

12. Watts A, Addy M. Tooth discoloration and staining: a review of the literature. Br Dent J. 2001 Mar;190(6):309-16. http://dx.doi.org/10.1038/sj.bdj.4800959. PMid:11325156.

13. Attin T, Manolakis A, Buchalla W, Hannig C. Influence of tea on intrinsic colour of previously bleached enamel. J Oral Rehabil. 2003 May;30(5):488-94. http://dx.doi.org/10.1046/j.1365-2842.2003.01097.x. PMid:12752928.

14. Ley M, Wagner T, Bizhang M. The effect of different fluoridation methods on the red wine staining potential on intensively bleached enamel in vitro. Am J Dent. 2006 Apr;19(2):80-4. PMid:16764129.

15. Matis BA, Wang G, Matis JI, Cook NB, Eckert GJ. White diet: is it necessary during tooth whitening? Oper Dent. 2015 May-Jun;40(3):235-40. http://dx.doi.org/10.2341/14-019-LIT. PMid:25748208.

16. Singh RD, Ram SM, Shetty O, Chand P, Yadav R. Efficacy of casein phosphopeptide-amorphous calcium phosphate to prevent stain absorption on freshly bleached enamel: an in vitro study. J Conserv Dent. 2010 Apr-Jun;13(2):76-9. http://dx.doi.org/10.4103/0972-0707.66715. PMid:20859479.

17. Carlos NR, Pinto AVD, Amaral FLB, França FMG, Turssi CP, Basting RT. Influence of staining solutions on color change and enamel surface properties during at-home and in-office dental bleaching: an in situ study. Oper Dent. 2019 Nov-Dec;44(6):595-608. http://dx.doi.org/10.2341/18-236-C. PMid:31034349.

18. Joiner A. The bleaching of teeth: a review of the literature. J Dent. 2006 Aug;34(7):412-9. http://dx.doi.org/10.1016/j.jdent.2006.02.002. PMid:16569473.

19. Kugel G, Petkevis J, Gurgan S, Doherty E. Separate whitening effects on enamel and dentin after fourteen days. J Endod. 2007 Jan;33(1):34-7. http://dx.doi.org/10.1016/j.joen.2006.07.012. PMid:17185126.

20. Leonard RH Jr, Bentley CD, Haywood VB. Salivary pH changes during 10\% carbamide peroxide bleaching. Quintessence Int. 1994 Aug;25(8):547-50. PMid:7568702.

21. Mori AA, Lima FF, Benetti AR, Terada RSS, Fujimaki M, Pascotto RC. Susceptibility to coffee staining during enamel remineralization following the in-office bleaching technique: an in situ assessment. J Esthet Restor Dent. 2016 Mar;28(Suppl 1):S23-31. http://dx.doi.org/10.1111/jerd.12134. PMid:25640880.

22. De Geus JL, De Lara MB, Hanzen TA, Fernández E, Loguercio AD, Kossatz S, et al. One-year follow-up of at-home bleaching in smokers before and after dental prophylaxis. J Dent. 2015 Nov;43(11):1346-51. http://dx.doi.org/10.1016/j.jdent.2015.08.009. PMid:26303401.

23. Carey CM. Tooth whitening: what we now know. J Evid Based Dent Pract. 2014 Jun;14(Suppl):70-6. http://dx.doi.org/10.1016/j.jebdp.2014.02.006. PMid:24929591.

24. Arévalo Pineda M, Larrucea Verdugo C. Dental bleaching regression caused by chromogenic beverages. In vitro. Rev Clín Periodoncia Implantol Rehabil Oral. 2012;5(2):57-65. http://dx.doi.org/10.4067/S0719-01072012000200001.

25. Nogueira BCL, Fernandes PM, Paiva ACJ, Fagundes NCF, Teixeira FB, Lima RR. Avaliação comparativa da ultraestrutura e propriedades físicas do esmalte bovino, bubalino e humano. Pesq Vet Bras. 2014;34(5):485-90. http://dx.doi.org/10.1590/S0100-736X2014000500017.

\section{CONFLICTS OF INTERESTS}

The authors declare no conflicts of interest. 


\section{*CORRESPONDING AUTHOR}

João Victor Frazão Câmara, USP - Universidade de São Paulo, Faculdade de Odontologia de Bauru, Departamento de Ciências Biológicas, Alameda Doutor Octávio Pinheiro Brisolla, 9-75 Jardim Brasil, 17012-901, Bauru - SP, Brasil, e-mail: jvfrazao92@hotmail.com

Received: June 27, 2020

Accepted: August 11, 2020 